\section{LA RELACIÓN ENTRE POLÍTICA Y VIOLENCIA EN EL PRT-ERP DURANTE LA «DESVIACIÓN MILITARISTA» DE LOS AÑOS 1971-1972}

\author{
THE RELATIONSHIP BETWEEN POLITICS AND \\ VIOLENCE IN THE PRT-ERP DURING THE «MILI- \\ TARIST DEVIATION» OF THE YEARS 1971-1972 \\ MARCO IAZZETTA .
}

Marco lazzetta es becario posdoctoral del CONICET y docente de Teoría Política II en la Facultad de Ciencia Política y Relaciones Internacionales de la

\section{Resumen}

El PRT-ERP es una de las únicas organizaciones armadas de izquierda de la Argentina que durante los años setentas proclamaba la necesidad de separar la organización política de la militar, concibiendo a ésta supeditada a la primera a partir de la idea de que «la política debe dirigir al fusil». El presente trabajo tiene por objeto analizar la tensión entre una concepción de la política que la reduciría a la guerra y otros dos sentidos que los consideramos como matices de esta primera concepción: el primero entiende a la política como lucha y la coloca en el mismo nivel que otras formas de lucha, entre ellas la militar; y la segunda profesa un papel rector de la política sobre el aspecto militar. Para ello, nos circunscribiremos a los años 1971-1972, conocidos como de «desviación militarista», pues durante este período la tensión entre estas diferentes concepciones de la política permaneció latente sin una resolución definitiva, por más que ya se observe una primacía del sentido que la iguala a la guerra.
Universidad Nacional de Rosario. e-mail: marcoiaz@hotmail.com

\section{Summary}

The PRT-ERP was one of the only left-wing armed force organizations in Argentina that during the 70's stated the need to divide the political organization from the military one. However, both organizations were deeply linked to one another and their main motto was that «the use of guns should be modeled by politics». This paper analyzes the tension between one conception of politics that reduces it to war and two other conceptions that are taken from the first conception: the former defines politics as a struggle and places it at the same level of other types of struggle (e.g. military struggles, etc.); and the latter refers to politics as a guiding principle over the military organization. In this article, we will limit our analysis to the years 1971-1972, known as "military deviation», because it was during this period that the tension between these different conceptions of politics kept latent without a definite resolution, although it is clear that the main concept was politics as a form of war. 